JIPVA (JURNAL PENDIDIKAN IPA VETERAN)

Volume 3-Nomor 2, 2019

Available athttp://e-journal.ivet.ac.id/index.php/jipva

ISSN : 2598-5876 (print), 2598-0904 (online)

\title{
Peningkatan aktivitas belajar IPA melalui real science mask menggunakan role playing model
}

\author{
Erna Noor Savitri*1 ${ }^{1}$, Retnaningsih ${ }^{2}$ \\ Jurusan IPA Terpadu, Fakultas Matematika dan Ilmu Pengetahuan Alam, Universitas Negeri \\ Semarang ${ }^{1}$, Jawa Tengah, Indonesia \\ SMP Negeri 10 Semarang $^{2}$, Jawa Tengah, Indonesia \\ *Coressponding author email: ernanoors@mail.unnes.ac.id
}

\section{Artikel info}

Received : 24 Sept. 2019

Revised : 04 November 2019

Accepted : 18 November 2019

\section{Kata kunci:}

Real science mask

Aktivitas belajar

Role playing

\section{ABSTRAK}

Pembelajaran IPA dapat dilakukan dengan meningkatkan peran peserta didik secara langsung (scientific activities). Penelitian ini bertujuan untuk meningkatkan aktivitas belajar peserta didik dalam pembelajaran melalui real science mask menggunakan role playing model materi reproduksi sel dan sistem reproduksi. Metode penelitian adalah penelitian tindakan dengan tiga siklus. Langkah-langkah setiap siklus terdiri dari perencanaan, pelaksanaan, observasi, dan refleksi. Data dianalisis dengan teknik analisis deskriptif. Subjek penelitian ini adalah peserta didik kelas IX B di SMPN 10 Semarang tahun pelajaran 2019/2020 sebanyak 34 peserta didik. Hasil penelitian pada siklus I diperoleh persentase pencapaian aktivitas belajar sebesar $65 \%$, pada siklus II sebesar 74\%, serta pada siklus III diperoleh persentase sebesar $85 \%$. Berdasarkan hasil penelitian terjadi peningkatan nilai aktivitas belajar peserta didik dari siklus I, II dan III. Adanya selisih nilai persentase untuk tiap siklusnya menunjukkan bahwa penelitian tindakan kelas yang dilakukan telah berhasil dalam meningkatkan aktivitas belajar peserta didik.

\section{ABSTRACT}

Keywords:

Real science mask

Learning activity

Role playing

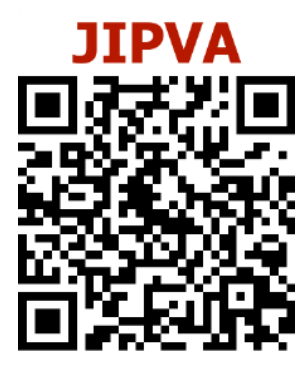

The Improvement of Science Learning Activities through Real Science Mask with Role-Playing Model. This study intended to enrich students' learning activities using real science masks with the role-playing model on cell-reproduction and reproduction system topics. The research method is action research with three cycles. The steps of each cycle comprised planning, implementing, observing, and reflecting. Data were analyzed with descriptive analysis technique. The subjects of this study were class IX B students at SMPN 10 Semarang in the 2019/2020 school year as many as 34 students. The results showed that in the cycle I, the average value was 7.85 from a total value of 12 . The achievement percentage of learning activities undertaken by the students in the first cycle was 65\%. In cycle II, the average value was 8.88 and the achievement percentage of learning activities was $74 \%$. It showed there has been an increase in the value of students' learning activities from the cycle I. The achievement percentage of learning activities undertaken by the students in the third cycle was 85\%, which means that there has been an increase in the value of students' learning activities from cycle II. The difference in percentage values for each cycle showed that the classroom action research conducted has been successful in increasing the students' learning activities. https://doi.org/10.31331/jipva.v3i2.958

How to Cite: Savitri, E. N., \& Retnaningsih. (2019). Peningkatan aktivitas belajar IPA melalui real science mask menggunakan role playing model. JIPVA (Jurnal Pendidikan IPA Veteran), 3(2), 149-164. doi: https://doi.org/10.31331/jipva.v3i2.958

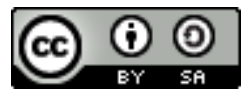

Copyright (C) 2019, Savitri \& Retnaningsih 


\section{PENDAHULUAN}

Pembelajaran merupakan suatu aktivitas yang kompleks, serta penggunaan metode dan media dalam pembelajaran dapat memberikan pengaruh yang positif terhadap hasil belajar peserta didik (Wahyudin, Sutikono, \& Isa, 2010; Widiyawati \& Nurwahidah, 2018). Proses belajar mengajar dapat berhasil dengan baik jika peserta didik diajak untuk memanfaatkan semua alat indra yang dimiliki (Arsyad, 2002). Semakin banyak alat indra yang digunakan untuk menerima dan mengelola informasi, maka semakin besar pula informasi tersebut untuk dapat dimengerti dan dipertahankan dalam ingatan (Munirah, 2014). Oleh karena itu, dibutuhkan stimulus yang baik dan menarik dalam proses pembelajaran. Guru harus dapat membangkitkan stimulus untuk mampu merangsang keterkaitan neuronneuron dalam otak peserta didik sehingga pembelajaran IPA dapat bermakna (Sesmiarni, 2014).

Pembelajaran IPA menyediakan berbagai pengalaman belajar untuk memahami konsep dan proses sains sehingga peserta didik dapat memecahkan masalah yang berkaitan dengan lingkungan serta masyarakat (Hayati \& Berlianti, 2016; Situmorang, 2017). Pada pembelajaran IPA, guru perlu mengetahui karakteristik pembelajaran sehingga tidak hanya menekankan IPA sebagai produk saja, tetapi pembelajaran yang menekankan pada proses untuk dapat memahami suatu konsep yang akan ditemui (Siregar \& Huda, 2010); Hayati \& Berlianti, 2016). Guru harus memilih metode pembelajaran yang cocok untuk materi yang akan diajarkan agar menambah minat belajar peserta didik dan akan mempengaruhi aktivitas belajar peserta didik di dalam kelas (Damayanti, Dahlan, \& Herrhyanto, 2018). Dalam menciptakan suasana pembelajaran yang berpusat pada peserta didik, pembelajaran IPA dapat dilakukan dengan mengurangi peran guru dalam ceramah dan meningkatkan peran peserta didik dalam pembelajaran IPA secara langsung (scientific activities). Pembelajaran IPA secara kontekstual merangsang peserta didik dapat memperoleh pengalaman langsung, sehingga dapat meningkatkan kekuatan potensinya untuk mencari, menyimpan dan menerapkan konsep yang telah dipelajarinya. Dengan demikian, peserta didik terlatih untuk dapat menemukan sendiri berbagai konsep yang dipelajari secara holistik, bermakna, otentik dan aktif. Pada aplikasinya, pembelajaran IPA dengan pendekatan kontekstual memberi andil pada teori belajar konstruktivisme sosial yang dikembangkan oleh Vygotsky (Maknun, 2014). Fitriani, Widiyatmoko, \& Khusniati (2016) menyatakan bahwa pembelajaran IPA yang banyak melibatkan peserta didik akan dapat meningkatkan aktivitas peserta didik di dalam kelas. Kegiatan tersebut mendorong peserta didik untuk berperan aktif dalam proses pembelajaran seperti pengamatan, pengujian, dan penelitian.

Hasil observasi peneliti di SMP Negeri 10 Semarang menunjukkan bahwa guru telah menggunakan metode pembelajaran diskusi dalam proses pembelajaran IPA. Akan tetapi, tidak semua peserta didik terlibat aktif dalam kegiatan tersebut. Ada beberapa peserta didik yang kurang antusias dalam proses pembelajaran, misalnya aktivitas bertanya dan kurang berinteraksi saat diskusi dengan teman kelompok. Selain itu, terdapat pula peserta didik yang kurang memperhatikan penjelasan guru, serta rendahnya respon peserta didik dalam mengajukan pertanyaan, menjawab pertanyaan, dan memberikan pendapat. Pada saat pembelajaran biasanya hanya $30 \%$ peserta didik yang inisiatif untuk aktif dalam pembelajaran, sedangkan yang lain hanya berdasarkan atas perintah guru. Kurangnya minat 
peserta didik mengikuti pembelajaran IPA menyebabkan peserta didik belum mencapai kriteria ketuntasan minimal (KKM) yang ditetapkan sekolah yaitu 71. Khusus pada materi sistem reproduksi, peserta didik cenderung menganggap materi tersebut adalah materi yang sulit dan tabu untuk dipelajari. Peserta didik cenderung malu dan pasif ketika membahas mengenai sistem reproduksi sehingga materi tidak dapat terserap dengan baik.

Aktivitas belajar pada penelitian ini yaitu aktivitas belajar peserta didik dalam mengikuti pembelajaran IPA melalui real science mask menggunakan role playing model. Aktivitas yang dinilai adalah aktivitas mendengarkan, lisan, dan menulis. Aktivitas belajar peserta didik akan mendorong kemampuan kognitifnya. Semakin aktif peserta didik dalam kegiatan pembelajaran berarti peserta didik lebih banyak melibatkan alat indera mereka sehingga diharapkan semakin banyak ilmu yang akan terserap (Munirah, 2014). Hal ini juga berpengaruh terhadap kemampuan kognitif peserta didik (Nahadi, Firman, \& Farina, 2015).

Mengacu pada kurangnya aktivitas belajar peserta didik di kelas, maka guru dapat menggunakan metode pembelajaran yang menjadikan peserta didik lebih aktif, suasana pembelajaran menjadi lebih efektif dan menyenangkan yaitu melalui real science mask menggunakan role playing model. Role playing model adalah suatu aktivitas pembelajaran terencana yang dirancang untuk mencapai tujuan-tujuan pendidikan yang spesifik dan menarik (Fitriyah \& Febyanto, 2015; Kristin, 2018). Keuntungan penggunaan real science mask menggunakan role playing model dalam pembelajaran, antara lain pada waktu dilaksanakannya bermain peran, peserta didik dapat bertindak dan mengekspresikan perasaan dan pendapat tanpa khawatir mendapat sanksi serta mereka dapat pula mengurangi dan mendiskusikan isu-isu yang bersifat manusiawi dan pribadi tanpa ada kecemasan. Pembelajaran menggunakan model bermain peran dapat meningkatkan aktivitas dan hasil belajar siswa (Widodo \& Widayanti, 2013). Selain itu dengan menerapkan model bermain peran akan muncul hubungan yang aktif antara siswa dengan siswa maupun siswa dengan guru (Fitriyah \& Febyanto, 2015). Oleh karena itu, tujuan dari penelitian ini adalah mengetahui ada atau tidaknya peningkatan aktivitas belajar peserta didik melalui real science mask menggunakan role playing model pada mata pelajaran IPA kelas IX-B SMP Negeri 10 Semarang.

Menurut Hyndman \& Mahony (2018), pengembangan kognitif atau intelektual peserta didik dapat dihasilkan, dikembangkan, dan ditransformasikan melalui aktivitas fisik dengan kegiatan bermain yang menyenangkan di sekolah. Aktivitas peserta didik dalam kegiatan belajar adalah untuk mengkonstruksi pengetahuan mereka sendiri. Peserta didik aktif membangun pemahaman atas persoalan atau segala sesuatu yang dihadapi dalam proses pembelajaran. Dengan demikian dapat disimpulkan bahwa aktivitas peserta didik dalam belajar merupakan segala kegiatan yang bersifat fisik maupun non fisik peserta didik dalam proses pembelajaran yang optimal, sehingga dapat menciptakan suasana kelas menjadi kondusif.

Aktivitas peserta didik dalam proses pembelajaran dapat merangsang dan mengembangkan bakat yang dimilikinya. Peserta didik juga perlu berlatih untuk berfikir kritis agar dapat memecahkan permasalahan-permasalahan dalam kehidupan sehari-hari (Sari \& Sugiyarto, 2015) sehingga mampu mengembangkan kemapuan berpikirnya menuju tingkat yang lebih tinggi (Nurwahidah, 2018). Di samping itu, guru juga dapat merekayasa sistem pembelajaran secara sistematis, sehingga merangsang keaktifan peserta didik dalam proses 
pembelajaran (Ningzaswati, Marhaeni, \& Suastra, 2015). Faktor-faktor yang dapat menumbuhkan timbulnya keaktifan peserta didik dalam proses pembelajaran, yaitu 1) Memberikan motivasi atau menarik perhatian peserta didik, sehingga mereka berperan aktif dalam kegiatan pembelajaran; 2) Menjelaskan tujuan instruksional (kemampuan dasar kepada peserta didik); 3) Mengingatkan kompetensi belajar kepada peserta didik; 4) Memberikan stimulus (masalah, topik, dan konsep yang akan dipelajari); 5) Memberikan petunjuk kepada peserta didik cara mempelajari; 6) Memunculkan aktivitas, partisipasi peserta didik dalam kegiatan pembelajaran, 7) Memberikan umpan balik (feedback); 8) Melakukan tagihantagihan kepada peserta didik berupa tes sehingga kemampuan peserta didik selalu terpantau dan terukur; 9) Menyimpulkan setiap materi yang disampaikan diakhir pembelajaran (Gagne \& Briggs, 1974).

Aktivitas peserta didik dapat ditingkatkan dan diperbaiki dalam keterlibatan peserta didik pada saat belajar. Belajar aktif adalah suatu sistem belajar mengajar yang menekankan keaktifan peserta didik secara fisik, mental intelektual dan emosional guna memperoleh hasil belajar yang berupa perpaduan antara aspek kognitif, afektif, dan psikomotor (Kadir, 2013). Belajar aktif sangat diperlukan oleh peserta didik untuk mendapatkan hasil belajar yang maksimal. Belajar aktif dapat dilihat dari segi siswa, yang berarti bahwa belajar aktif merupakan proses kegiatan yang dilakukan siswa dalam rangka belajar. Aktifitas ini dapat berupa aktifitas fisik, mental, maupun keduanya. Ada juga yang lebih menekankan pada keaktifan mental, meskipun untuk mencapai maksud ini dipersyaratkan keterlibatan langsung berbagai keaktifan fisik (Hasan Baharun, 2015). Menurut Dierich dalam Rusmawan, Candiasa, \& Parwati (2017), aktivitas belajar dapat dijabarkan dalam indikator-indikator pada Tabel 1.

Tabel 1. Indikator aktivitas peserta didik

\begin{tabular}{ll}
\hline \multicolumn{1}{c}{ Indikator Keaktifan } & \multicolumn{1}{c}{ Sub Indikator } \\
\hline Oral activities & Bertanya \\
& Menjawab \\
& Berpendapat \\
& Diskusi \\
& Menyimpulkan \\
Listening activities & Mendengarkan \\
Writing activities & Membuat catatan/mengerjakan LDS \\
Drawing activities & Membuat Grafik \\
Mental activities & Menanggapi \\
& Menganalisa \\
Emotional activities & Bersemangat \\
\hline
\end{tabular}

Terdapat bermacam-macam jenis aktivitas belajar peserta didik, tetapi tidak semua jenis aktivitas tersebut dilakukan oleh peserta didik dalam belajar IPA khususnya biologi. Pada penelitian ini aktivitas yang diamati adalah oral activities, listening activities, dan writing activities yang meliputi memberikan pendapat/tanggapan, diskusi, menyimpulkan, mendengarkan dan mencatat. Aktivitas-aktivitas tersebut dinilai penting dalam proses pembelajaran, khususnya pada materi reprodusi sel dan manusia. Aktivitas berupa oral activities, listening activities, dan writing activities akan mampu menggambarkan pemahaman siswa terhadap materi yang diajarkan. Penggunaan metode, pendekatan belajar mengajar dan 
orientasi belajar menyebabkan aktivitas belajar setiap peserta didik berbeda-beda. Ketidaksamaan aktivitas belajar peserta didik menghasilkan kadar aktivitas belajar yang bergerak dari aktivitas belajar yang rendah sampai aktivitas belajar yang tinggi (Djamarah \& Zain, 2006). Masalah yang dihadapi guru adalah bagaimana upaya untuk menggunakan model pembelajaran agar dapat meningkatkan aktivitas peserta didik. Ketepatan dalam penggunaan model pembelajaran yang dilakukan oleh guru akan dapat meningkatkan aktivitas dan prestasi belajar siswa (Agustina, Saputro, \& Mulyani, 2013). Hal ini merupakan tantangan bagi guru untuk merealisasikan dengan metode pembelajaran inovatif yang tepat (Yahya, 2014). Penelitian dari Pamelasari \& Khusniati (2014) variasi pada kegiatan belajar dapat meningkatkan motivasi belajar serta prestasi dalam memahami materi.

Role playing merupakan suatu aktivitas pembelajaran terencana yang dirancang untuk mencapai tujuan-tujuan pendidikan yang spesifik. Role playing dapat membuat peserta didik memiliki gambaran yang lebih konkret mengenai materi sedang dipelajarai melaui masing-masing peran yang dimainkan sehingga menciptakan pembelajaran yang lebih menyenangkan (Fitriyah \& Febyanto, 2015). Role playing model dilakukan melalui pengembangan imajinasi dan penghayatan yang dilakukan peserta didik dengan memerankan sebagai tokoh hidup atau benda mati.

Pada model role playing, proses pembelajaran ditekankan pada keterlibatan emosional dan pengamatan indra ke dalam suatu situasi masalah yang secara nyata dihadapi, baik guru maupun peserta didik. Ada beberapa keuntungan penggunaan model role playing dalam pembelajaran pada waktu dilaksanakannya bermain peran. Peserta didik dapat bertindak dan mengekpresikan perasaan dan pendapat tanpa khawatir mendapat sanksi. Langkah-langkah metode role playing menurut Uno (2009) dalam Baroroh (2011) adalah (1) Guru menyusun/menyiapkan skenario yang akan ditampilkan; (2) Menunjuk beberapa peserta didik untuk mempelajari skenario dua hari sebelum KBM; (3) Guru membentuk kelompok peserta didik yang anggotanya kurang lebih 5 orang; (4) Memberikan penjelasan tentang kompetensi yang ingin dicapai; (5) Memanggil para peserta didik yang sudah ditunjuk untuk memerankan scenario yang sudah dipersiapkan; (6) Masing-masing peserta didik duduk di kelompoknya dan memperhatikan mengamati skenario yang sedang diperagakan; (7) Setelah selesai diperankan, masing-masing peserta didik diberikan kertas sebagai lembar kerja untuk membahas; (8) Masing-masing kelompok menyampaikan hasil kerja kelompoknya; (9) Guru memberikan simpulan secara umum; (10) Evaluasi; (11) Penutup.

Pembelajaran menggunakan role playing model akan merangsang peserta didik untuk dapat bermain peran sesuai dengan materi yang diajarkan oleh guru (Effendi, 2013; Fitriyah \& Febyanto, 2015). Dalam pembelajaran ini aktivitas peserta didik akan terbentuk menjadi lebih aktif dan pemahaman peserta didik tentang materi akan meningkat karena peserta didik secara langsung terlibat dalam pembelajaran. Untuk itu, agar pembelajaran dapat memperoleh hasil yang baik, perlu adanya stimulus yang baik dan menarik sehingga peserta didik dapat memberikan respon berupa aktivitas dan hasil belajar yang baik pula. Cara belajar yang baik dapat dicapai dalam suasana tanpa tekanan dan paksaan serta suasana yang menyenangkan bagi peserta didik. Salah satu metode yang dilakukan adalah belajar sambil bermain. Permainan sangat efektif untuk menjelaskan pengertian yang abstrak dan konsep yang sulit dijelaskan dengan kata-kata (Machin, 2012). Metode permainan dapat mengembangkan bahasa, emosi, disiplin dan kreativitas. Melalui bermain, perkembangan sosial siswa dapat 
berkembang, seperti belajar berkomunikasi, mengorganisasi peran, menghargai orang lain dan menaati peraturan (Nugroho, Raharjo, \& Wahyuningsih, 2013).

Real science mask menggunakan role playing model mengharuskan peserta didik untuk bermain peran, mengasah kemampuan komunikasi dan aktivitas belajarnya. Peserta didik harus menguasai materi pembelajaran melalui pengembangan imajinasi dan penghayatan peserta didik dengan memerankannya sebagai tokoh hidup atau benda mati dengan menggunakan real science mask. Adapun tujuan dari model role playing menggunakan real science mask adalah merubah pemahaman peserta didik menjadi perilaku, sehingga peserta didik akan merasakan langsung dan dapat menambah pengalaman belajar dengan menggunakan bantuan indera pendengaran dan penglihataan serta alat bantu lainnya. Dengan memanfaatkan indra pendengaran dan penglihatan, memudahkan peserta didik dalam menerima dan memahami materi yang didapat peserta didik. Selain itu materi yang diterima akan lebih melekat pada memori jangka panjangnya (Munirah, 2014).

\section{METODE}

Penelitian ini merupakan penelitian tindakan kelas (classroom action research). Penelitian tindakan kelas (classroom action research) bersifat reflektif dan kolaboratif serta dilakukan dengan tujuan untuk memperbaiki kegiatan pembelajaran di kelas sehingga dapat tercapai hasil yang diinginkan (Widodo \& Widayanti, 2013). Penelitian tindakan kelas yang dilakukan bertujuan untuk meningkatkan pemahaman konsep peserta didik pada kelas IXB SMP Negeri 10 Semarang tahun pelajaran 2019/2020 melalui real science mask menggunakan role playing model pada mata pelajaran IPA. Rancangan penelitian yang digunakan adalah rancangan model penelitian tindakan, berbentuk siklus. Penelitian dilaksanakan dalam tiga siklus, dan langkah-langkah setiap siklus terdiri dari perencanaan, pelaksanaan, observasi, dan refleksi. Visualisasi gambar proses penelitian tindakan kelas ini tampak pada Gambar 1.

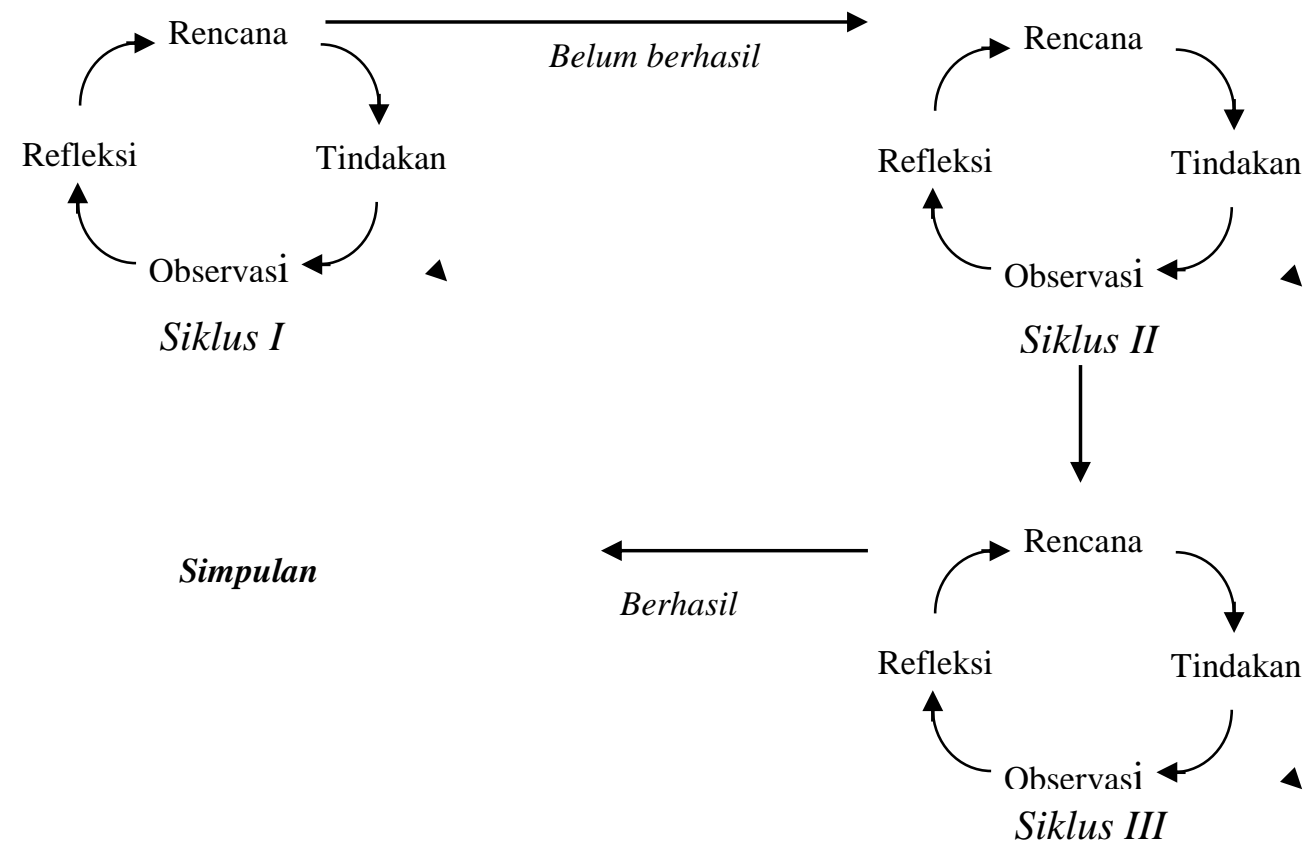

Gambar 1. Proses penelitian tindakan kelas 
Penelitian tindakan kelas menurut Wijayanti (2013) merupakan penelitian berdaur ulang yang dilakukan guru untuk perbaikan dalam proses pembelajaran. Penelitian ini dilakukan dengan akar permasalahan benar-benar dihadapi peserta didik (masalah konkret di dalam kelas, dirasakan sebagian besarpeserta didik, dan muncul terus menerus). Apabila setelah dilaksanakan siklus I belum mencapai indikator keberhasilan, maka penelitian dilanjutkan pada siklus II. Tiap siklus terdiri dari perencanaan, pelaksanaan tindakan, observasi dan refleksi.

\section{Refleksi awal}

Refleksi awal mencakup evaluasi terhadap hasil observasi awal yang meliputi keadaan pembelajaran, performa guru, performa peserta didik. Peneliti menganalisis permasalahan yang ada di dalam pembelajaran sebelumnya.

\section{Siklus I}

\section{Rencana tindakan}

Rencana tindakan ini terdiri dari, (a) menyusun silabus dan RPP yang didalamnya mengandung unsur real science mask menggunakan model pembelajaran role playing; (b) Menyiapkan lembar observasi dan tes untuk mengukur hasil belajar kognitif dan aktivitas belajar peserta didik. Pertemuan pertama pada siklus I, materi yang diajarkan adalah reproduksi sel. Pada materi ini peserta didik menjelaskan fase-fase pembelahan mitosis dan meiosis melalui real science mask menggunakan role playing model kemudian mengidentifikasi perbedaan pembelahan mitosis dan meiosis.

\section{Pelaksanan Tindakan}

Pada tahap ini peneliti dan observer mengimplementasikan seluruh rencana tindakan yang telah dipersiapkan. Silabus dan RPP diimplementasikan oleh peneliti dan guru kelas yang bertindak sebagai fasilitator dalam kegiatan pembelajaran. Pada akhir siklus, diberikan tes kepada peserta didik untuk mengukur kemampuan kognitif.

\section{Observasi}

Observasi dilakukan oleh peneliti bersama dengan guru sebagai observer. Kegiatan observasi dilakukan dengan tidak mengganggu proses pembelajaran. Fokus kegiatan observasi meliputi peningkatan aktivitas belajar peserta didik.

\section{Refleksi I}

Data hasil pengukuran selama pelaksanaan tindakan yang diperoleh dengan pengukuran melalui observasi dan tes dijadikan dasar untuk melakukan refleksi I. Refleksi dilakukan peneliti dan observer dengan cara menganalisis dan mengevaluasi data yang terkumpul. Hasil refleksi I dijadikan panduan untuk menyusun rencana tindakan II.

\section{Siklus II dan III}

Tahap-tahap penelitian dalam siklus II dan III serupa dengan siklus I yaitu rencana tindakan, pelaksanaan tindakan, observasi, dan refleksi. Rencana tindakan II didasarkan pada temuan-temuan observasi dan refleksi I. Siklus III didasarkan pada temuan-temuan observasi dan refleksi II. Kegiatan pada siklus II diberikan tambahan tindakan berupa permainan menggunakan puzzle dan pada siklus III ditambahkan video pembelajaran sebelum peserta didik melakukan role playing. Batasan dalam pengukuran hasil belajar kognitif peserta didik 
adalah minimal 25 dari 34 peserta didik telah mencapai atau melampaui nilai sesuai KKM 71 maka penelitian dianggap berhasil.

Penelitian ini dilaksanakan di SMPN 10 Semarang yang beralamat di Jalan Jl.Menteri Supeno No. 1, Kota Semarang, Provinsi Jawa Tengah, Indonesia. Pelaksanaan penelitian akan dilakukan pada kelas IXB semester gasal tahun ajaran 2019/2020. Subjek yang digunakan pada penelitian ini adalah peserta didik kelas IX B di SMPN 10 Semarang tahun pelajaran 2019/2020 sebanyak 34 peserta didik yang mempunyai kemampuan akademis yang heterogen dan latar belakang yang berbeda. Sumber data dalam penelitian ini berkaitan dengan asal penelitian guna memperoleh data-data yang dibutuhkan untuk bahan kajian dalam analisis data. Sumber data yang digunakan dalam penelitian ini meliputi (1) Informan atau narasumber yaitu guru kelas IX B SMP Negeri 10 Semarang; (2) Peristiwa pembelajaran, yaitu proses pembelajaran selama di dalam kelas khususnya pembelajaran melalui real science mask menggunakan role playing model pada mata pelajaran IPA; (3) Dokumen dan arsip, yaitu informasi tertulis berupa perangkat pembelajaran.

Metode pengumpulan data yang digunakan adalah metode observasi. Metode observasi digunakan untuk mengumpulkan data peserta didik dalam kegiatan pembelajaran. Pemberian lembar observasi diberikan untuk mengungkap aktivitas belajar peserta didik saat kegiatan pembelajaran. Lembar observasi tersebut diberikan sebelum pembelajaran untuk dilakukan pengamatan saat pembelajaran melalui real science mask menggunakan role playing model. Lembar observasi terdiri dari pernyataan yang mampu mengukur kemampuan oral activities, listening activities, dan writing activities. Nilai oral activities diambil berdasarkan kemampuan peserta didik dalam kemampuan mengemukakan pendapat sesuai dengan materi dengan bahasa baik dan sopan. Nilai listening activities diambil berdasarkan kemampuan bekerjasama dan menghargai pekerjaan dan pendapat teman. Nilai writing activities diambil berdasarkan kemampuan peserta didik dalam melaporkan hasil pembelajaran secara lengkap, sistematis dan rapi. Pengamatan dilakukan oleh guru dan 2 observer yaitu peneliti dan dibantu oleh 1 orang mahasiswa. Observasi dalam penelitian ini dilakukan secara langsung saat peserta didik melakukan kegiatan pembelajaran melalui real science mask menggunakan role playing model.

Pengujian alat pengumpulan data yang digunakan dalam penelitian tindakan kelas ini dilakukan menggunakan validitas konstruk (construct validity). Menurut Djaali \& Muljono (2008), validitas konstruk adalah validitas yang mempermasalahkan seberapa jauh item-item tes mampu mengukur apa yang benar-benar hendak diukur sesuai dengan konsep khusus atau definisi konseptual yang telah ditetapkan. Pada PTK kali ini peneliti menggunakan instrumen berbentuk skala likert dan observasi yang digunakan untuk mengukur aktivitas belajar peserta didik dalam kegiatan pembelajaran. Analisis data penelitian ini pada prinsipnya menggunakan teknik analisis kuantitatif. Analisis kuantitatif dilihat berdasarkan nilai ketuntasan pada saat PTK antar siklus. Nilai ketuntasan minimal yang telah ditentukan sekolah pada mata pelajaran IPA adalah 71, sehingga apabila pada siklus I masih terdapat siswa yang belum tuntas, maka penelitian akan dilanjut ke siklus II dengan perbaikan kegiatan pembelajaran yang telah dilakukan pada siklus I. Perbaikan tersebut dilakukan untuk memperbaiki jika terdapat kelemahan-kelemahan dalam kegiatan pembelajaran yang telah dilakukan pada siklus I sehingga aktivitas belajar siswa peserta didik dapat meningkat. Apabila pada siklus II juga belum tercapai, maka akan berlanjut ke siklus III demikian seterusnya sampai dengan tercapai 
nilai ketuntutasan tersebut. Melalui real science mask menggunakan role playing model pada pembelajaran IPA di kelas IXB SMPN 10 Semarang, diharapkan ada peningkatan aktivitas belajar peserta didik. Target aktivitas belajar peserta didik pada penelitian ini adalah minimal 25 dari 34 peserta didik telah mencapai mencapai skor 10 dari skor total 12. Jika sudah mencapai target yang diharapkan, maka penelitian dianggap berhasil.

Keterlaksanaan penerapan pembelajaran melalui real science mask menggunakan role playing model dideskripsi dengan foto dan video kegiatan selama proses pembelajaran tiap siklus. Aktivitas belajar peserta didik dideskripsikan dalam bentuk grafik dan dilakukan pemaparan secara kualitatif sehingga dapat tergambarkan peningkatan aktivitas belajar peserta didik dalam pembelajaran dengan baik.

Penelitian tindakan kelas menurut Wijayanti (2013) merupakan penelitian berdaur ulang dilakukan guru untuk perbaikan proses pembelajaran. Penelitian dilakukan dengan akar permasalahan benar-benar dihadapi peserta didik (masalah konkret di dalam kelas, dirasakan sebagian besar peserta didik, dan muncul terus menerus). Penelitian dilaksanakan 3 siklus. Apabila setelah dilaksanakan siklus I belum mencapai indikator keberhasilan, maka dilanjutkan siklus II.

\section{HASIL DAN PEMBAHASAN}

Penelitian tindakan kelas ini dilakukan di SMP Negeri 10 Semarang yang beralamat di Jalan J1. Menteri Supeno No. 1, Kota Semarang, Provinsi Jawa Tengah, Indonesia. Pada Penelitian Tindakan Kelas ini subjek penelitian adalah kelas IX B yang terdiri dari 19 peserta didik laki-laki dan 17 peserta didik perempuan. Pengamatan dilakukan pada aktivitas belajar siswa untuk tiap siklusnya. Pengamatan dilakukan dengan observasi menggunakan menggunakan rubrik dibantu oleh observer dan guru kelas.

\section{Pra Siklus}

Pada penelitian ini kegiatan awal yang dilakukan adalah melakukan observasi untuk mengetahui aktivitas belajar peserta didik ketika proses pembelajaran IPA sedang berlangsung. Observasi dilakukan pada tanggal 29-31 Juli 2019. Peneliti mengamati proses belajar mengajar pada materi reproduksi sel. Melalui kegiatan observasi tersebut diketahui bahwa proses pembelajaran dilakukan dengan sistem diskusi dan presentasi. Berdasarkan kegiatan observasi tersebut, peserta didik kelas IXB yang aktif bertanya pada saat kegiatan pembelajaran didominasi oleh peserta didik yang berprestasi tinggi di kelas sedangkan beberapa peserta didik yang lain terlihat kurang antusias pada proses pembelajaran yang sedang dilakukan. Hal ini menunjukkan bahwa terjadi ketimpangan dalam hal keaktifan peserta didik di dalam proses pembelajaran antara siswa yang berprestasi dan yang kurang berprestasi di dalam kelas. Terlihat bahwa tingkat prestasi siswa di dalam kelas berbanding lurus dengan keaktifannya dalam kegiatan pembelajaran. Berdasarkan kegiatan observasi menunjukkan bahwa masih ada siswa yang kurang tertarik mengikuti proses pebelajaran IPA yang sedang dilaksanakan sehingga mereka cenderung pasif pada proses pembelajaran tersebut.

Refleksi awal mencakup evaluasi terhadap hasil observasi awal yang meliputi keadaan pembelajaran, performa guru, performa peserta didik. Peneliti menganalisis permasalahan yang ada di dalam pembelajaran sebelumnya. Hasil refleksi awal antara lain, (1) Hasil 
aktivitas belajar peserta didik masih kurang terlihat dari beberapa peserta didik yang pasif dikelas dan hanya didominasi oleh beberapa peserta didik saja yang aktif; (2) Beberapa peserta didik tidak dapat mengemukakan pendapat terkait materi yang diajarkan di dalam kelas; (3) Perlunya real science mask menggunakan role playing model untuk meningkatkan aktivitas belajar peserta didik. Aktivitas peserta didik dalam proses pembelajaran perlu ditingkatkan agar hasil belajar siswa juga meningkat (Widodo \& Widayanti, 2013). Hal ini yang masih perlu ditingkatkan pada proses pembelajaran IPA yang terjadi di SMP Negeri 10 Semarang. Agar terjadi peningkatan aktivitas peserta didik diperlukan pembenahan dalam proses pembelajaran sehingga dapat mewujudkan pembelajaran yang efektif dan bermakna (Widodo \& Widayanti, 2013; Iskandar, 2014; Yuliati, 2017). Dalam mewujudkan kegiatan pembelajaran yang efektif tersebut guru harus mengurangi kegiatan ceramah sehingga memberikan ruang yang lebih banyak agar peserta didik yang lebih aktif di dalam kelas.

\section{Siklus I}

Tindakan pembelajaran pada siklus I dilaksanakan dalam 1 kali pertemuan. Pertemuan pertama dilaksanakan pada hari Kamis tanggal 1 Agustus 2019. Materi pokok yang dipelajari pada penelitian siklus I adalah reproduksi sel (mitosis dan meiosis). Hasil pengamatan aktivitas belajar peserta didik pada siklus I diperoleh nilai rata-rata 7,85 dari nilai total sebesar 12. Persentase pencapaian aktivitas belajar yang dilakukan peserta didik pada siklus I sebesar $65 \%$. Berdasarkan hasil analisis deskriptif terhadap aktivitas belajar peserta didik pada siklus I, menunjukkan bahwa rata-rata nilai aktivitas belajar siswa 7,85. Beberapa faktor yang menyebabkan aktivitas belajar peserta didik belum maksimal adalah penerapan real science mask yang merupakan hal baru bagi peserta didik, sehingga peserta didik masih belum maksimal dalam memahaminya sehingga hasil dari nilai aktivitas belajar belum maksimal. Hal tersebut dapat dilihat dari pemahaman narasi yang sesuai dengan real science mask yang terlalu lama dari batas waktu yang sudah ditentukan oleh guru, peserta didik yang salah menjelaskan materi, dan sikap kerjasama antar peserta didik yang masih kurang.

Faktor lain yang menyebabkan kurang maksimalnya aktivitas belajar adalah pemahaman real science mask secara berkelompok. Sesuai Rencana Pelaksanaan pembelajaran (RPP) yang telah disusun, bahwa pembelajaran melalui real science mask menggunakan role playing model dikerjakan secara berkelompok. Hal tersebut membuat peserta didik kurang berpartisipasi saat memahami real science mask. Selain itu, peserta didik masih belum terbiasa menggunakan metode tersebut.

Berdasarkan analisis keadaan dan data pada siklus I, guru bersama observer melakukan refleksi terhadap faktor-faktor yang menyebabkan kurang maksimalnya nilai kognitif dan aktivitas belajar peserta didik dalam pembelajaran melalui real science mask menggunakan role playing model, yaitu (1) manajemen waktu dalam pelaksanaan siklus I masih kurang optimal, dalam hal ini manajemen saat kegiatan diskusi. Hal itu terlihat dari perlunya tambahan waktu saat diskusi menggunakan real science mask dan (2) kegiatan presentasi tidak merata antar semua kelompok karena efisiensi waktu yang kurang baik.

Berdasarkan hasil refleksi tersebut, langkah-langkah perbaikan yang dilakukan pada siklus II, yaitu sebagai berikut (1) pemahaman real science mask dilakukan secara individu. Akan tetapi kegiatan diskusi tetap dilakukan secara berkelompok, agar peserta didik dapat berdiskusi dan bertukar pendapat tentang materi yang dicantumkan real science mask; (2) 
selama pembelajaran berlangsung, guru harus lebih sering mengingatkan kepada peserta didik tentang waktu maksimal pengerjaan real science mask; (3) kegiatan presentasi hasil real science mask dilakukan secara acak, sehingga semua peserta didik dapat bersiap-siap untuk mempertanggungjawabkan hasil real science mask yang telah dibuat; dan (4) ditambahkan kegiatan menyusun puzzle agar peserta didik bertambah pengetahuan awalnya sebelum bermain menggunakan real science mask.

Berdasarkan hasil analisis dan refleksi tersebut di atas, guru melakukan perbaikanperbaikan dalam mengajarkan materi selanjutnya, yakni sistem reproduksi manusia yang diterapkan pada siklus 2 serta memperbaharui kegiatan pembelajarn sesuai yang diharapkan agar aspek kognitif dan aktivitas belajar peserta didik dapat lebih ditingkatkan lagi khususnya pada peserta didik kelas IXB SMP N 10 Semarang.

\section{Siklus II}

Tindakan pembelajaran pada siklus II dilaksanakan pada tanggal 5-7 Agustus 2019. Hasil penelitian siklus I secara keseluruhan sudah mencapai indikator keberhasilan, namun masih ada beberapa hal yang perlu diperbaiki dan ditingkatkan. Oleh karena itu, peneliti melanjutkan penelitian siklus II. Kegiatan yang dilakukan pada siklus II hampir sama dengan siklus I. Hasil pengamatan aktivitas belajar peserta didik pada siklus II diperoleh nilai ratarata 8,88 dari total nilai 12 . Persentase aktivitas belajar peserta didik pada siklus II sebesar $74 \%$ telah melaksanakan aktivitas belajar, hal tersebut menunjukkan terjadi peningkatan nilai aktivitas belajar peserta didik dari siklus I. Peningkatan nilai aktivitas belajar pada siklus II tercermin pada lebih aktifnya kegiatan yang dilakukan peserta didik pada saat pembelajaran. Berdasarkan hasil analisis deskriptif terhadap aktivitas belajar peserta didik pada siklus II menunjukkan adanya peningkatan dari siklus I. Aktivitas belajar juga telah menunjukkan peningkatan yaitu telah mencapai $74 \%$ peserta didik yang aktif melakukan aktivitas belajar yang baik. Beberapa faktor yang menyebabkan aktivitas belajar peserta didik masih dapat ditingkatkan lagi adalah tindak lanjut dari pembuatan real science mask. Akan lebih baik jika ada tindak lanjut yang lebih membuat peserta didik tertantang setelah membuat real science mask. Hal tersebut memungkinkan aktivitas belajar peserta didik lebih meningkat lagi.

Meskipun terjadi peningkatan aktivitas peserta didik, tetap dilaksanakan siklus III untuk memantapkan hasil penelitian dan memastikan bahwa hasil yang diperoleh sudah benar-benar baik. Oleh karena itu, dilakukan refleksi pada siklus II. Berdasarkan hasil refleksi tersebut, langkah-langkah perbaikan yang dilakukan pada siklus III, yaitu pertama selama pembelajaran berlangsung, guru harus dapat mengorganisasikan waktu dengan baik.uru lebih sering mengingatkan kepada peserta didik tentang waktu maksimal memahami real science mask. Kedua, kegiatan presentasi hasil real science mask dilakukan secara acak, sehingga semua peserta didik dapat bersiap-siap untuk mempertanggungjawabkan hasil diskusi dan pemahaman yang telah dibuat.

Berdasarkan hasil analisis dan refleksi tersebut di atas, guru melakukan perbaikanperbaikan dan pemantapan dalam mengajarkan materi selanjutnya, yakni mengenai penyakit reproduksi yang diterapkan pada siklus 3 serta memperbaharui kegiatan pembelajarn sesuai yang diharapkan agar hasil kognitif dan aktivitas belajar peserta didik dapat lebih ditingkatkan lagi khususnya pada peserta didik kelas IXB SMP N 10 Semarang. 


\section{Siklus III}

Tindakan pembelajaran pada siklus III dilaksanakan pada tanggal 8-12 Agustus 2019. Hasil penelitian siklus III secara keseluruhan sudah mencapai indikator keberhasilan. Kegiatan yang dilakukan pada siklus III hampir sama dengan siklus II. Hasil pengamatan aktivitas belajar peserta didik pada siklus III diperoleh nilai rata-rata 10,21dari total nilai 12 . Persentase aktivitas belajar peserta didik pada siklus III sebesar $85 \%$ berarti telah terjadi peningkatan nilai aktivitas belajar peserta didik dari siklus II. Peningkatan nilai aktivitas belajar pada siklus II tercermin pada lebih aktifnya kegiatan yang dilakukan peserta didik pada saat pembelajaran.

Peningkatan aktivitas belajar terlihat signifikan yang ditunjukkan dengan nilai persentase sebesar $85 \%$ peserta didik telah mengikuti kegiatan pembelajaran. Hal ini juga ditunjukkan dengan lebih banyak peserta didik yang berperan aktif saat pembelajaran berlangsung dibandingkan dengan siklus sebelumnya. Nilai rata-rata tiap siklus dapat dilihat pada gambar 2 .

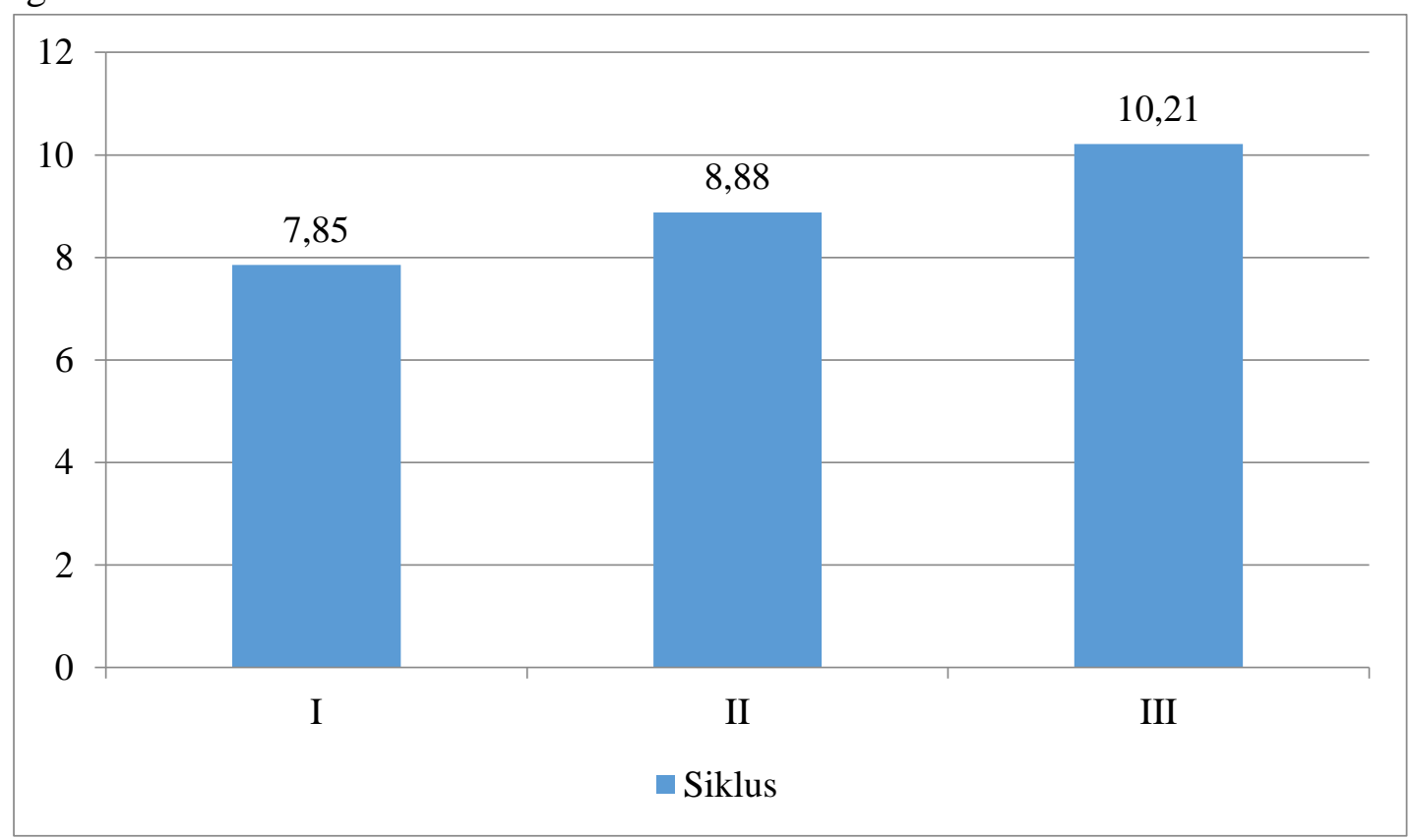

Gambar 2. Grafik rata-rata nilai aktivitas belajar peserta didik antar siklus

Gambar 2 menunjukkan bahwa terdapat peningkatan rata-rata nilai aktivitas belajar peserta didik antara siklus I, II dan III. Peningkatan dari siklus I ke siklus yang kedua cukup baik namun tidak terlalu signifikan seperti kenaikan aktivitas peserta didik yang terjadi pada siklus II ke siklus III. Nilai rata-rata pada siklus I belum maksimal karena masih terdapat beberapa kelemahan dalam teknis pelaksanaan penelitian. Kelemahan yang paling terlihat pada siklus yang pertama adalah mengenai manajemen waktu. Hal ini kemudian diperbaiki pada siklus yang ke II. Selain itu perbedaan lain yaitu pada siklus I pembelajaran real science mask dilakukan secara berkelompok dan ternyata kurang efektif karena beberapa peserta didik masih pasif. Berdasarkan hal tersebut, pada siklus II real science mask dilakukan secara individu, namun ada kegiatan diskusi yang harus dilakukan secara berkelompok. Pada pelaksanaannya siklus II berjalan lebih baik sehingga nilai rata-rata pada siklus II meningkat. Penelitian dilanjutkan ke siklus yang ke III karena dalam pelaksanaan pembelajaran real 
science mask menggunakan role playing model masih memerlukan tindak lanjut agar peningkatan aktivitas peserta didik lebih maksimal. Dan setelah dilakukan siklus yang ke III, ternyata nilai rata-rata tertinggi aktivitas belajar peserta didik berada pada siklus III yang mencapai 10 dari total nilai 12.

Peningkatan aktivitas belajar peserta didik pada setiap siklus tersebut menandakan bahwa kualitas kegiatan pembelajaran peserta didik mulai meningkat pada setiap siklusnya. Hasil penelitian yang dilakukan menunjukkan bahwa pelaksanaan pembelajaran dengan penerapan real science mask menggunakan role playing model dapat memberikan hasil yang lebih baik terhadap aktivitas peserta didik pada proses pembelajaran IPA pada kelas IXB di SMP Negeri 10 Semarang.

Hal ini sesuai dengan penelitian-penelitian sebelumnya bahwa penerapan model bermain peran dalam proses pembelajaran dapat meningkatkan aktivitas belajar peserta didik sehingga hasil belajar juga dapat meningkat (Alfianto, Sulistiono, \& Utami, 2013; Fuad, 2014; Fitriyah \& Febyanto, 2015; Kristin, 2018). Dengan adanya real science mask menggunakan role playing model tersebut membuat peserta didik lebih aktif dalam memahami materi pembelajaran. Selain itu pembelajaran dengan role playing model juga dapat meningkatkan kecerdasan interpersonal peserta didik (Dewi, Purwanto, \& Wibowo, 2016) sehingga peserta didik menjadi lebih aktif pada proses pembelajaran. Pelaksanaan pembelajaran dengan penerapan real science mask menggunakan role playing model merupakan langkah nyata dalam melakukan pembelajaran IPA yang menekankan pada proses untuk dapat memahami suatu konsep dengan baik (Siregar \& Huda, 2010); Hayati \& Berlianti, 2016). Berdasarkan hasil analisis dan refleksi dari 3 siklus, penelitian dianggap selesai, karena indikator ketercapaian aktivitas belajar peserta didik meningkat signifikan yakni sebesar $85 \%$ peserta didik telah aktif mengikuti kegiatan pembelajaran.

\section{SIMPULAN DAN SARAN}

\section{Simpulan}

Berdasarkan hasil penelitian dan pembahasan yang telah disajikan, maka dapat disimpulkan bahwa melalui real science mask menggunakan role playing model dapat meningkatkan aktivitas belajar peserta didik kelas IXB SMP N 10 Semarang pada mata pelajaran IPA. Real science mask menggunakan role playing model dapat meningkatkan nilai aktivitas belajar peserta didik kelas IXB SMP Negeri 10 Semarang dengan peningkatan pada siklus I mencapai 7,85 (65\%) dan siklus II mencapai 8,88 (74\%) dan meningkat lagi pada siklus III sebesar 10,21 (85\%). Real science mask menggunakan role playing model layak digunakan dalam pembelajaran khususnya di kelas IXB SMP N 10 Semarang karena terbukti dapat meningkatkan aktivitas belajar peserta didik.

\section{Saran}

Saran pada penelitian ini merupakan saran dari peneliti berkaitan dengan Real science mask menggunakan role playing model dalam pembelajaran. Saran yang dapat peneliti berikan yaitu real science mask menggunakan role playing model perlu disosialisasikan agar lebih sering diterapkan dalam pembelajaran di sekolah untuk meningkatkan aktivitas belajar peserta didik. 


\section{DAFTAR PUSTAKA}

Agustina, E., Saputro, A., \& Mulyani, S. (2013). Penggunaan metode pembelajaran jigsaw berbantuan handout untuk meningkatkan aktivitas dan prestasi belajar siswa pada materi pokok hidrokarbon kelas XC SMA Negeri 1 Gubug tahun ajaran 2012/2013. Jurnal Pendidikan Kimia (JPK), 2(4), 66-71. Retrieved from http://jurnal.fkip.uns.ac.id/index.php/kimia/article/view/2775

Alfianto, A. B., Sulistiono, \& Utami, B. (2013). Penerapan model bermain peran pada materi sistem pernapasan terhadap aktivitas dan hasil belajar siswa kelas VIII SMPN 1 Semen Kediri. In Seminar Nasional XII Pendidikan Biologi FKIP UNS (pp. 476-480). Retrieved from https://jurnal.uns.ac.id/prosbi/article/view/6976/6204

Arsyad, A. (2002). Media pembelajaran, edisi 1. Jakarta: PT. Raja Grafindo Persada.

Baroroh, K. (2011). Upaya meningkatkan nilai-nilai karakter peserta didik melalui penerapan metode role playing. Jurnal Ekonomi Dan Pendidikan, 8(2), 8-16. https://doi.org/10.21831/jep.v8i2.793

Damayanti, D., Dahlan, J. A., \& Herrhyanto, N. (2018). Penerapan metode accelerated learning dalam pembelajaran matematika untuk meningkatkan kemampuan komunikasi matematis siswa SMP. Jurnal Integral, 9(2), 15-24. https://doi.org/10.1017/CBO9781107415324.004

Dewi, E. R., Purwanto, E., \& Wibowo, M. E. (2016). Model bimbingan kelompok dengan teknik role play berbasis pendekatan BCCT untuk meningkatkan kecerdasan interpersonal siswa PAUD. Jurnal Bimbingan Konseling, 5(2), 93-99. Retrieved from https://journal.unnes.ac.id/sju/index.php/jubk/article/view/14025

Djaali, H., \& Muljono, P. (2008). Pengukuran dalam bidang pendidikan. Jakarta, Grasindo.

Djamarah, S. B., \& Zain, A. (2006). Strategi belajar mengajar. Jakarta: Rineka Cipta.

Effendi, M. (2013). Integrasi pembelajaran active learning dan internet-based learning dalam meningkatkan keaktifan dan kreativitas belajar. Jurnal Pendidikan Islam, 7(2), 283-308. https://doi.org/10.21580/nw.2013.7.2.563

Fitriani, N. R., Widiyatmoko, A., \& Khusniati, M. (2016). The Effectiveness of CTL model guided inquiri-based in the topic of chemicals in daily life to improve students' learning outcomes and activeness. Jurnal Pendidikan IPA Indonesia, 5(2), 278-283. https://doi.org/10.15294/jpii.v5i2.6699

Fitriyah, C. Z., \& Febyanto, H. (2015). Model bermain peran untuk meningkatkan aktivitas dan hasil belajar siswa pada mata pelajaran IPS di Sekolah Dasar. PEDAGOGIA: Jurnal Pendidikan, 4(1), 34-40. https://doi.org/10.21070/pedagogia.v4i1.70

Fuad, M. (2014). Pengaruh model bermain peran dan TAI dengan motivasi belajar terhadap prestasi belajar tematik. Jurnal Ilmu Sosial Dan Humaniora, 1(1), 21-27. Retrieved from http://www.stkippgri-lmg.ac.id/e-journal/index.php/jojs/article/view/9

Gagne, R. M., \& Briggs, L. J. (1974). Principles of instructional design. Holt, Rinehart \& Winston.

Hasan Baharun. (2015). Penerapan pembelajaran active learning untuk meningkatkan hasil belajar siswa di Madrasah. Jurnal Pendidikan Pedagogik, 01(01), 34-46. Retrieved from https://ejournal.unuja.ac.id/index.php/pedagogik/article/view/14

Hayati, N., \& Berlianti, N. A. (2016). Peningkatan aktivitas dan hasil belajar mahasiswa universitas hasyim asy'ari melalui pembelajaran discovery terbimbing. JPBI (Jurnal Pendidikan Biologi Indonesia), 2(3), 206-214. https://doi.org/10.22219/jpbi.v2i3.3857

Hyndman, B., \& Mahony, L. (2018). Developing creativity through outdoor physical activities: a qualitative exploration of contrasting school equipment provisions. Journal of Adventure Education and Outdoor Learning, 18(3), 242-256. https://doi.org/10.1080/14729679.2018.1436078 
Iskandar, S. M. (2014). Pendekatan keterampilan metakognitif dalam pembelajaran sains di kelas. $\quad$ Erudio, 2(2), 13-20. Retrieved from https://erudio.ub.ac.id/index.php/erudio/article/view/151

Kadir, A. (2013). Konsep pembelajaran kontekstual di sekolah. Dinamika Ilmu, 13(3), 17-38. https://doi.org/10.21093/di.v13i1.20

Kristin, F. (2018). Meta-analisis pengaruh model pembelajaran role playing terhadap hasil belajar IPS. Refleksi Edukatika: Jurnal Ilmiah Kependidikan, 8(2). https://doi.org/10.24176/re.v8i2.2356

Machin, A. (2012). Pengaruh permainan call cards terhadap hasil belajar dan aktivitas pembelajaran biologi. Jurnal Pendidikan IPA Indonesia, 1(2), 163-167. https://doi.org/10.15294/jpii.v1i2.2134

Maknun, D. (2014). Penerapan pembelajaran kontekstual untuk meningkatkan literasi sains dan kualitas argumentasi siswa pondok pesantren Daarul Uluum PUI Majalengka pada diskusi sosiosaintifik IPA. JURNAL TARBIYAH, 21(1), 119-148. https://doi.org/10.30829/tar.v21i1.221

Munirah, M. (2014). Upaya peningkatanmutu hasil belajar melalui media pembelajaran. AULADUNA: Jurnal Pendidikan Dasar Islam, 1(1), 80-88. Retrieved from http://journal.uin-alauddin.ac.id/index.php/auladuna/article/viewFile/543/538

Nahadi, N., Firman, H., \& Farina, J. (2015). Effect of feedback in formative assessment in the student learning activities on chemical course to the formation of habits of mind. Jurnal Pendidikan IPA Indonesia, 4(1), 36-42. https://doi.org/10.15294/jpii.v4i1.3499

Ningzaswati, D. R., Marhaeni, M. A. P. A. A. I. N., \& Suastra, M. P. P. I. W. (2015). Pengaruh model pembelajaran kooperatif teknik time token terhadap aktivitas belajar dan hasil belajar IPA siswa kelas VI SD. Jurnal Program Pascasarjana Universitas Pendidikan Ganesha, 5(1), 1-12. Retrieved from https://media.neliti.com/media/publications/124768-ID-none.pdf

Nugroho, A. P., Raharjo, T., \& Wahyuningsih, D. (2013). Pengembangan media pembelajaran fisika menggunakan permainan ular tangga ditinjau dari motivasi belajar siswa kelas VIII materi gaya. Jurnal Pendidikan Fisika, 1(1), 11-18. Retrieved from http://jurnal.fkip.uns.ac.id/index.php/pfisika/article/view/1769

Nurwahidah, I. (2018). Pengembangan soal penalaran model TIMSS untuk mengukur high order thinking (HOT). Thabiea : Journal of Natural ScienceTeaching, 01(01), 20-29. https://doi.org/10.21043/thabiea.v1i1.3874

Pamelasari, S. D., \& Khusniati, M. (2014). Keefektifan metode schoolyard inquiry terhadap peningkatan pemahaman science vocabulary. Jurnal Pendidikan IPA Indonesia, 3(2), 177-182. https://doi.org/10.15294/jpii.v3i2.3118

Rusmawan, I. P. H. G., Candiasa, I. M., \& Parwati, N. N. (2017). Instrumen penilaian aktivitas belajar matematika siswa SD berorientasi pendidikan karakter. Wahana Matematika Dan Sains: Jurnal Matematika, Sains, Dan Pembelajarannya, 11(2), 125139. https://doi.org/10.23887/wms.v11i2.12587

Sari, D. S., \& Sugiyarto, K. H. (2015). Pengembangan multimedia berbasis masalah untuk meningkatkan motivasi belajar dan kemampuan berpikir kritis siswa. Jurnal Inovasi Pendidikan IPA, 1(2), 153-166. https://doi.org/10.21831/jipi.v1i2.7501

Sesmiarni, Z. (2014). Kecerdasan jamak dalam pembelajaran IPA di Sekolah Dasar. TERAMPIL Jurnal Pendidikan Dan Pembelajaran Dasar, 1(2), 180-189. https://doi.org/10.24042/terampil.v1i2.1315

Siregar, M. D., \& Huda, N. (2010). Pengaruh pembelajaran quantum dalam pembelajaran IPA terhadap motivasi belajar dan penguasaan konsep siswa kelas IV SDN 3 Pancor. Jurnal Educatio, 5(1), 58-68. https://doi.org/10.29408/edc.v5i1.116 
Situmorang, R. P. (2017). Integrasi literasi sains peserta didik dalam pembelajaran sains. Satya Widya, 32(1), 49-56. https://doi.org/10.24246/j.sw.2016.v32.i1.p49-56

Wahyudin, Sutikono, \& Isa, A. (2010). Keefektifan pembelajaran berbantuan multimedia menggunakan metode inkuiri terbimbing untuk meningkatkan minat dan pemahaman siswa. Jurnal Pendidikan Fisika Indonesia, 6(1), 58-62. https://doi.org/10.15294/jpfi.v6i1.1105

Widiyawati, Y., \& Nurwahidah, I. (2018). Elclivs berbasis inquiry untuk meningkatkan penguasaan konsep siswa tuna netra pada materi rangkaian listrik. Jurnal Inovasi Pendidikan IPA, 4(2), 212-223. https://doi.org/10.21831/jipi.v4i2.21527

Widodo, \& Widayanti, L. (2013). Peningkatan aktivitas belajar dan hasil belajar siswa dengan metode problem based learning pada siswa kelas VIIA MTs Negeri Donomulyo Kulon Progo tahun pelajaran 2012/2013. Jurnal Fisika Indonesia, 17(49), 32-35. https://doi.org/10.22146/jfi.24410

Wijayanti, E. (2013). Peningkatan kualitas pembelajaran IPA melalui model STAD dengan media crossword puzzle pada siswa kelas IV SD Islam Al Madina. Universitas Negeri Semarang. Retrieved from lib.unnes.ac.id/17523/1/1401409040.pdf

Yahya, N. (2014). Model pembelajaran berbasis proyek berbantuan media kultur jaringan untuk meningkatkan aktivitas dan kreativitas siswa kelas XII Ipa2 SMA Negeri 1 Bangsri. Jurnal Pendidikan IPA Indonesia, 3(2), 154-159. https://doi.org/10.15294/jpii.v3i2.3115

Yuliati, Y. (2017). Literasi sains dalam pembelajaran IPA. Jurnal Cakrawala Pendas, 3(2), 21-28. https://doi.org/10.31949/jcp.v3i2.592

\section{PROFIL SINGKAT}

Erna Noor Savitri, S.Si., M.Pd., lahir di Yogyakarta, 07 Agustus 1985, meraih gelar Sarjana Sains (S.Si) jurusan Biologi di Universitas Gadjah Mada pada tahun 2007 dan Magister Pendidikan (M.Pd) jurusan Pendidikan Sains Konsentrasi Biologi di Universitas Sebelas Maret pada tahun 2012. Saat ini bekerja sebagai dosen di jurusan IPA Terpadu FMIPA Universitas Negeri Semarang. Email: ernanoors@mail.unnes.ac.id

Dra. Retnaningsih lahir di Kebumen pada tanggal 24 Oktober 1968. Pendidikan terakhir adalah Sarjana dan pada saat ini bekerja sebagai guru. 